\title{
Full-Scale Composting of Different Mixtures with Meal from Dead Pigs: Process Monitoring, Compost Quality and Toxicity
}

\author{
Lucas L. C. Guidoni ${ }^{1}$ (1) . Gabriel A. Martins ${ }^{2} \cdot$ Miguel F. Guevara $^{1} \cdot$ João N. Brandalise ${ }^{3}$. Thomaz Lucia Jr. ${ }^{4}$. \\ Michel D. Gerber ${ }^{5} \cdot$ Luciara B. Corrêa $^{1} \cdot$ Érico K. Corrêa ${ }^{1}$
}

Received: 15 October 2020 / Accepted: 8 March 2021 / Published online: 21 March 2021

(C) The Author(s), under exclusive licence to Springer Nature B.V. 2021

\begin{abstract}
Abundant by-products of large swine industries, such as slaughterhouse sludge and carcasses, require adequate treatment to prevent negative effects of their direct disposal in the open environment. This study is aimed to evaluate the efficiency of composting using meal from dead pigs through physicochemical analyses and phytotoxic assays. Five treatments were tested, all including 50\% sawdust: T1, with 50\% slaughterhouse sludge (control); T2, with 20\% slaughterhouse sludge and 30\% meal from dead pigs; T3, with 10\% slaughterhouse sludge and 40\% meal from dead pigs; T4, with $20 \%$ organic stabilizing compost and 30\% meal from dead pigs and T5, with 30\% organic stabilizing compost and $20 \%$ meal from dead pigs. The phytotoxicity assays used lettuce, cucumber, celia, soybean, rice and wheat as bioindicators. Inclusion of meal from dead pigs was related to reduction in $\mathrm{pH}, \mathrm{C} / \mathrm{N}$ ratio, humidity and temperatures inside the pile, although thermophilic peaks lasted longer than 50 days and the final composts showed high content of nitrogen and phosphorous. The germination of bioindicators was reduced in all tested treatments, compared to the control. The composts from treatments that included meal from dead pigs presented acceptable nutrient content, which may indicate their use as organic fertilizers. However, after 4 months, all bioindicators in contact with such composts presented impaired germination.
\end{abstract}

\section{Graphic Abstract}
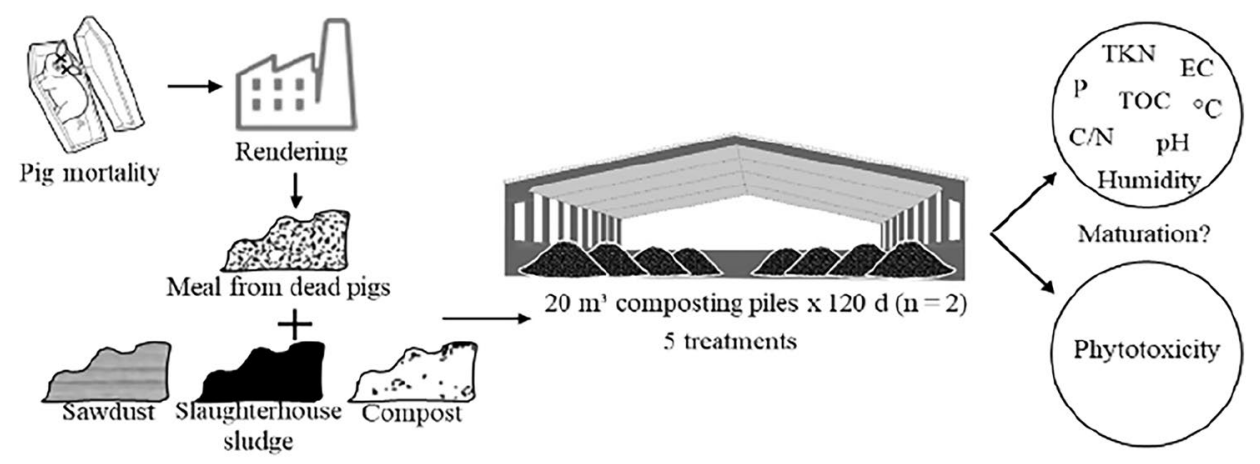

Keywords Pig mortality $\cdot$ Animal rendering $\cdot$ Agro-industrial waste $\cdot$ Co-composting $\cdot$ Organomineral fertilizer . Phytotoxicity

Érico K. Corrêa

ericokundecorrea@yahoo.com.br

1 NEPERS, Centro de Engenharias, Universidade Federal de Pelotas, Pelotas, RS, Brazil

2 Ciência e Tecnologia de Alimentos, Faculdade de Agronomia Eliseu Maciel, Universidade Federal de Pelotas, Pelotas, RS, Brazil
3 Instituto de Biologia, Universidade Federal de Pelotas, Pelotas, RS, Brazil

4 ReproPel, Faculdade de Veterinária, Universidade Federal de Pelotas, Pelotas, RS, Brazil

5 Instituto Federal de Educação, Ciência e Tecnologia Sul-Rio-Grandense, Pelotas, RS, Brazil 


\section{Statement of Novelty}

We believe that this article contributes for the concept of waste recovery technology. Additionally, our study suggests a sustainable alternative to reduce the environmental impact of the disposal of dead pigs outside slaughterhouses. Thus, considering parameters of quality and maturation of the compost, chemical fertilizers may eventually be replaced through the transformation of agro-industrial residues into organic fertilizers rich in nutrients, with the objective of reducing pollution.

\section{Introduction}

Brazil is among the world's leading pork producers, along with China, USA and the European Union [1]. In all such markets, as farm inventories are generally large, a great number of pigs are slaughtered at industrial abattoirs, generating substantial volumes of effluents and biosolid sludge after process in treatment systems [2]. At farm level, mortality is an alarming source of waste of meat production, commonly occurring in all production stages: $7-10 \%$ in gestation and farrowing; and 5-7\% in nursery, growing and finishing [3]. This includes pigs died due to routine health conditions and accidents and those that were euthanized. However, in case of widespread disease outbreaks, such as the recent African Swine Fever epidemic in China [4] and the Covid-19 pandemic [5], massive populational euthanasia would generate an uncommonly large disposal of dead animals.

Pigs that die or are euthanized at farms are ineligible for slaughter at commercial abattoirs, generating a large volume of carcasses, which may be buried, burned, incinerated, submitted to alkaline hydrolysis, composted or recycled [6]. The disposal of such material in the environment without criteria may lead to the release of unpleasant odor, pollution of soil and water sources and greenhouse gas emissions, due to its high organic content $[7,8]$. Thus, recycling of such carcasses has become increasingly used in plants specifically designed to centralize large-scale processing of inedible products, due to biosecurity reasons [9]. Such process includes cutting, mixing and cooking the carcasses under controlled temperature, pressure and time, to allow the subsequent separation of oils, fats and tallows and grinding of the dry matter [10]. The resulting meal from dead pigs may be destined to incineration for energy production [11], to direct disposal in soils [12], and to anaerobic digestion [13]. As occurs with conventional meat and bone meals with varying levels of available nitrogen in the initial mixtures [14], both the slaughterhouse sludge and the meal from dead pigs can also be used on composting, generating a compost rich in humified organic matter and mineral salts with potential use in agriculture.

On a laboratory scale, previous studies reported the inclusion of $5-7 \%$ of meat/blood/bone meal obtained in slaughterhouses from animal by-products to compost mixtures [14], with the mixture with a structuring agent reaching a volumetric ratio of 1:2 [15]. However, although meat/bone meal from animal by-products (with a market value of US\$ $1500 /$ ton) is commonly used for animal nutrition, similar meals obtained from carcasses of dead animals cannot be destined for animal nutrition, generating additional costs related to their disposal. In Brazil, the legislation determines that the compost should have a maximum 50\% humidity, a minimum $\mathrm{pH}$ of 6.0 , a minimum nitrogen content of $0.5 \%$ and a $\mathrm{C} / \mathrm{N}$ ratio of at most 20/1 [16]. Thus, the inclusion of meal from dead pigs in the composting process may allow improvement on nutrient availability to the microbiota compost pile, resulting in a nutrient-rich compost that may be used in agriculture as an organic fertilizer, adding value to such type of waste.

However, composting efficiency includes the use of correct mixing ratio, the optimization of various processes such as aeration rate, $\mathrm{C} / \mathrm{N}$ ratio, moisture content and the use of an adequate bulking agent [17]. The composition of the mixtures and the load of animal by-products can be limiting for biological processes of digestion, due to the amount of protein and lipids that may inhibit microbial activity [13]. With $\mathrm{C} / \mathrm{N}$ ratio lower than $15 / 1$ at the beginning of composting, increase in ammonia volatilization, electrical conductivity and phytotoxicity may occur [18]. On the other hand, a reduced $\mathrm{C} / \mathrm{N}$ ratio does not prevent efficient composting, favoring the use of lower content of bulking agents [19]. The addition of bulking agents may optimize composting, influencing interactions between biochemical and physical characteristics during the process [17]. Sawdust, straw, brans, trims and branches are some commonly used as bulking agents. Partially decomposed organic material from the thermophilic phase of composting [20] or mature (stable) compost $[21,22]$ also can be added to the mixture as inoculums, to accelerate microbial growth, altering a previously developed microorganism population.

During composting, materials are decomposed through the action of bacteria, fungi and actinomycetes, resulting in the production of stabilized organic matter and humus [23]. The process is completed when the compost achieves stability, when the microbial activity is reduced to an insignificant level, and maturity, when the phytotoxins are reduced to a safer level [24]. Nonetheless, the efficiency of composting cannot be evaluated considering only a single property, since physicochemical analyses and phytotoxicity assays are also relevant [25]. The efficiency of the composting treatments including sludge from agro-industrial wastewater treatment systems and sawdust was already reported [26, 
27]. However, considering that composts generated from treatments including meal from dead pigs may contribute to attenuate the dependence of agriculture on chemical fertilizers, the effects of the inclusion of such meals on the nutrient content and maturity of composts still needs to be investigated.

The objectives of this study were to evaluate the efficiency of composting with the inclusion of meal from dead pigs from a pilot rendering plant of animal by-products (destined for purposes other than animal consumption) in distinct combinations with pig slaughterhouse sludge from wastewater treatment system and bulking agents, by monitoring the evolution of the composting process over time, and the quality of the final compost, through physicochemical analyzes and phytotoxicity tests.

\section{Material and Methods}

\section{Composting and Raw Material}

The experiment was conducted in a covered industrial composting facility of animal recycling, located in southern Brazil, from August to November, which correspond to Spring in the southern hemisphere, during a period of 120 days. That was the standard composting period in the industry where the experiment was conducted, which is also within the periods suggested in other studies (90-150 days) [14, 28]. The facility had an impermeable concrete floor, $2-\mathrm{m}$ high lateral walls and a slurry containment and stormwater drainage systems at the back area. The meal from dead pigs came from a rendering plant that processed inedible products.

The tested materials were pig slaughterhouse sludge from a primary wastewater treatment system (coagulation, flocculation and centrifugation), eucalyptus sawdust from local logging companies and a stabilizing compost (used as an inoculum). These materials were mixed for composting in five treatments, all including a fixed 50\% sawdust as the bulking agent and the main source of carbon:

T1: sawdust and slaughterhouse sludge (50:50, v:v) was the control, since it was considered efficient in previous studies, based on physical-chemical stabilization [26] and absence of phytotoxicity [27].

T2: sawdust, slaughterhouse sludge and meal from dead pigs (50:20:30).

T3: sawdust, slaughterhouse sludge and meal from dead pigs (50:10:40).

T4: sawdust, stabilizing compost and meal from dead pigs (50:20:30).
T5: sawdust, stabilizing compost and meal from dead pigs (50:30:20).

In T2 and T3, different proportions of sludge with meal from dead pigs were tested, whereas distinct proportions of stabilizing compost with meal were tested n T4 and T5.

The treatments were mixed in elliptical piles with approximately $20 \mathrm{~m}^{3}$ each $(6 \mathrm{~m}$ long, $4 \mathrm{~m}$ large and $1.8 \mathrm{~m}$ high). The piles were randomly distributed at the floor, in duplicates, separated by $3-5 \mathrm{~m}$. The piles were turned and homogenized weekly until the 50th day with front-end loader, ensuring that the material in the outer zones were turned into the internal part of the pile. Thereafter, they were turned at 25-day intervals. Due to the low humidity visually detected in the composting material at the 60th day of the study, water was added to the piles, to provide greater humidity.

\section{Sampling and Physicochemical Parameters}

Samples of the two replications were collected in seven periods (at the 1st, 20th, 40th, 60th, 80th, 100th and 120th day), totaling 70 samples, weighing $1.0 \mathrm{~kg}$ each. Subsamples were taken from three central and equidistant points of the pile and mixed to ensure homogeneity. Thereafter, the samples were cooled at $5{ }^{\circ} \mathrm{C}$ and transported to the laboratory, where they were subsequently frozen at $-20{ }^{\circ} \mathrm{C}$. The temperature of the piles was recorded daily, at three radial points, at half height and at $60 \mathrm{~cm}$ depth, with a digital thermometer attached to a rod. The environmental temperature was also registered daily.

Laboratory quality control were ensured by the calibration of the equipment and by the preparation of standard curves. All samples were analyzed in triplicate. Electrical conductivity (MCA-150, MS Tecnopon ${ }^{\circledR}$, Brazil) and pH (MPA-210, MS Tecnopon ${ }^{\circledR}$, Brazil) were determined using a digital bench equipment, immediately after the cooled samples reached the laboratory. All other analyses were conducted in subsequently, in stored frozen samples. The humidity was determined in a drying oven (AOAC, 1990, method 950.01). The total organic Carbon was determined by the Walkley-Black method with heating, the Phosphorous content was measured through UV-visible spectrophotometry $(660 \mathrm{~nm})$ [18] and the total Nitrogen through the Kjedahl (TKN) digestion method (AOAC, 1990, method 955.04).

\section{Phytotoxicity Assays}

Six seeds were used as bioindicators in the phytotoxicity assays: lettuce (Lactuca sativa); cucumber (Cucumis 
sativus); celia (Celosia argentea); soybean (Glycine max); wheat (Triticum aestivum); and rice (Oryza sativa). An aqueous extract of samples of all treatments $(1: 10 ; \mathrm{w} / \mathrm{v})$ was prepared during $1 \mathrm{~h}$ in agitation, placed in petri dishes with 10 seeds of each species and subsequently incubated for $48 \mathrm{~h}$ at $25^{\circ} \mathrm{C}$ in the dark [29]. Samples including only distilled water (control) were also incubated. The germination index (GI) was calculated considering the relative germination and root elongation [30].

\section{Reference Limits for Compost Quality and Maturity}

Mean values for distinct treatments were compared against the reference values for composting recommended by the current Brazilian legislation [16] and with industry benchmarks [31]. The limits for the GI were adopted as a parameter to complement maturity assessments [31, 32].

\section{Statistical Analyses}

Descriptive statistics were generated to characterize the physicochemical parameters of the tested structuring materials. For all responses of interest, normality was checked using the Shapiro-Wilk test. Whenever lack of normality was detected, transformations were conducted to normalize the data.

Analysis of variance was used to compare the variation in physicochemical parameters across treatments, collection periods and potential treatment per period interactions. Likewise, the GI for the tested bioindicators were also compared among treatments, period of collection and potential interactions using analysis of variance. Subsequent comparisons of means were conducted through the Tukey test.
The variation over time was predicted for the physicochemical parameters that presented significant effect of the collection periods in those previous analyses (humidity, $\mathrm{pH}$, electrical conductivity, total Kjeldahl nitrogen, phosphorus and $\mathrm{C} / \mathrm{N}$ ratio), through linear regression models, including polynomial adjustments for non-linear variation.

\section{Results and Discussion}

\section{Raw Material Characterization}

The mean physicochemical characteristics and the GI of the raw materials used in composting are shown in Table 1 . The low $\mathrm{C} / \mathrm{N}$ ratio presented by both the slaughterhouse sludge and the meal from dead pigs indicates that such materials are a nitrogen source in the mixture, which is essential for the protein synthesis conducted by microorganisms. In contrast, sawdust would be a carbon source, which is a substrate for energy generation [19].

The low humidity presented by the meal from dead pigs (Table 1) may be due to its obtention through thermal digestion. That can be limiting in mixtures including only materials with humidity already close to the ideal for the composting process (40-60\%) [33], such as sawdust and the stabilizing compost. However, such condition can be balanced with the inclusion of slaughterhouse sludge, which presented the highest humidity among all raw materials used.

The greatest electrical conductivity observed for the mixtures including stabilizing compost may reflect the fact that this material was previously obtained from composting. Thus, the mineralization that occurred during composting likely resulted in a great concentration of compounds that

Table 1 Descriptive statistics (mean \pm SD) for the physicochemical characteristics and the germination index (GI) of distinct raw materials used in composting $(\mathrm{n}=70)$

\begin{tabular}{lllll}
\hline Parameter & Sawdust & Slaughterhouse sludge & Meal from dead pigs & Stabilizing compost \\
\hline Humidity (\%) & $53.9 \pm 0.2$ & $67.6 \pm 0.2$ & $7.4 \pm 0.5$ & $49.7 \pm 4.1$ \\
pH & $6.3 \pm 0.1$ & $5.4 \pm 0.3$ & $6.6 \pm 0.1$ & $6.8 \pm 0.1$ \\
Electrical conductivity (mS/cm) & $0.1 \pm 0.1$ & $1.0 \pm 0.1$ & $2.9 \pm 0.1$ & $3.5 \pm 0.1$ \\
Total Kjedahl N (\%) & $0.3 \pm 0.1$ & $5.8 \pm 0.1$ & $8.9 \pm 0.4$ & $2.6 \pm 0.1$ \\
C/N ratio & 166.1 & 7.2 & 4.3 & 16.9 \\
Phosphorus (\%) & $0.4 \pm 0.1$ & $2.8 \pm 0.1$ & $3.6 \pm 0.6$ & $1.9 \pm 0.1$ \\
GI lettuce (\%) & $97.2 \pm 42.2$ & 0.3 & 0.0 & 0.0 \\
GI cucumber (\%) & $52.2 \pm 43.8$ & $1.0 \pm 0.1$ & 0.0 & $0.4 \pm 0.5$ \\
GI celia (\%) & $115.1 \pm 20.0$ & 0.0 & $1.3 \pm 2.2$ & 0.0 \\
GI soybean (\%) & $155.7 \pm 47.1$ & $52.7 \pm 21.7$ & $20.9 \pm 10.5$ & $11.2 \pm 4.5$ \\
GI rice (\%) & $119.7 \pm 4.2$ & $37.6 \pm 9.3$ & $3.0 \pm 1.8$ & $4.2 \pm 5.9$ \\
GI wheat $(\%)$ & $36.5 \pm 19.5$ & $5.1 \pm 4.4$ & $3.0 \pm 1.8$ & $4.5 \pm 0.8$ \\
\hline
\end{tabular}


conduct electrical current, such as mineral salts released from decomposition of organic matter [17].

Although the $\mathrm{pH}$ was generally within the values expected for most tested materials [2], the most acid $\mathrm{pH}$ was observed for the slaughterhouse sludge (Table 1). It is important to emphasize that the contents of phosphorus and TKN in the meal from dead pigs and in the slaughterhouse sludge indicate their high potential to aggregate nutrients to the final compost.

Among all tested bioindicators, sawdust presented the lowest phytotoxicity (Table 1). Cucumber, celia and lettuce seeds would be the most sensitive to phytotoxicity since they presented the lowest overall GI. Soybean, rice and wheat seeds would be less sensitive to phytotoxicity when in contact with the tested structuring materials, although their germination was also impaired, and wheat seeds were prone to some phytotoxicity even when in contact with sawdust.

\section{Physicochemical Parameters}

Compared to the environmental temperature, all treatments generated higher temperatures already after the 5th day (Fig. 1). During the composting phases, the treatments including meal from dead pigs presented a similar temperature pattern over time. The initial phase lasted the first 4 days, followed by the thermophilic phase (5-50 days) and, finally, by the mesophilic maturation phase (50-120). The highest mean temperature throughout the period $\left(59.1{ }^{\circ} \mathrm{C}\right)$ was achieved by the control treatment (T1), which was different from the other treatments at the 20th day $(\mathrm{P}<0.05)$, which can be explained by the observed humidity (Fig. 2a) and $\mathrm{C} / \mathrm{N}$ ratio (Fig. 3b). Mixtures with meal from dead pigs showed lower humidity (> 30\%) and high nitrogen availability (C/N below 15:1), which may have affected the microbial metabolism activity, reflecting in temperatures lower than those of the control. For the control treatment, temperatures within the pile quickly reached $70{ }^{\circ} \mathrm{C}$ and remained above $60{ }^{\circ} \mathrm{C}$ until the 93 rd day. In the other treatments, with either reduced or no slaughterhouse sludge content, temperatures were lowered by nearly $10{ }^{\circ} \mathrm{C}$ compared to the control. Although mean overall temperatures did not differ $(\mathrm{P}>0.05)$ for the other treatments $\left(\mathrm{T} 2=46.8{ }^{\circ} \mathrm{C}\right.$; $\mathrm{T} 3=46.6{ }^{\circ} \mathrm{C}$; $\mathrm{T} 4=45.9^{\circ} \mathrm{C}$; and $\mathrm{T} 5=47.3^{\circ} \mathrm{C}$ ), all such treatments showed temperature peaks above $60^{\circ} \mathrm{C}$, indicating the occurrence of a thermophilic phase longer than 50 days. Such prolonged period of high temperatures may also have contributed for the excessive drying of the piles at the 60th day, which was mitigated by watering the piles. After that, coinciding with the interruption of the weekly turning, temperatures consistently declined in such treatments until values close to the environmental temperature were reached, suggesting that the compost was stabilizing.

The comparisons of physicochemical parameters across treatments (Table 2 ) indicated that the greatest humidity was observed in the control $(\mathrm{P}<0.05)$. Among the treatments including meal from dead pigs, T5 presented greater humidity than $\mathrm{T} 4(\mathrm{P}<0.05)$, but no other differences were observed $(\mathrm{P}>0.05)$. Linear regression models indicated that humidity declined linearly in all treatments $(\mathrm{P}<0.05)$, as composting was prolonged (Fig. 2a). In T1, the humidity was above the established upper limit (Table 3 ) until nearly 30 days of composting and declined subsequently, whereas the humidity was always below that upper limit in the other treatments. Nevertheless, the linear decrease in humidity was more characteristic in T4 and T5, which did not include slaughterhouse sludge, as indicated by the greater $R^{2}$ of their models. That can be attributed to the thermal digestion of such wastes, since the meal from dead pigs produced material with humidity inferior to $10 \%$ (Table 1 ). As such, inclusion of meal from dead pigs should be balanced with
Fig. 1 Temporal temperature profile (Mean $\pm \mathrm{SD}$ ) for composting treatments using distinct raw materials*. *T1 (control): sawdust and float sludge (50:50, v:v); T2: sawdust, float sludge and meal from dead pigs (50:20:30); T3: sawdust, float sludge and meal from dead pigs (50:10:40); T4: sawdust, stabilizing compost and meal from dead pigs (50:20:30); T5: sawdust, stabilizing compost and meal from dead pigs (50:30:20)

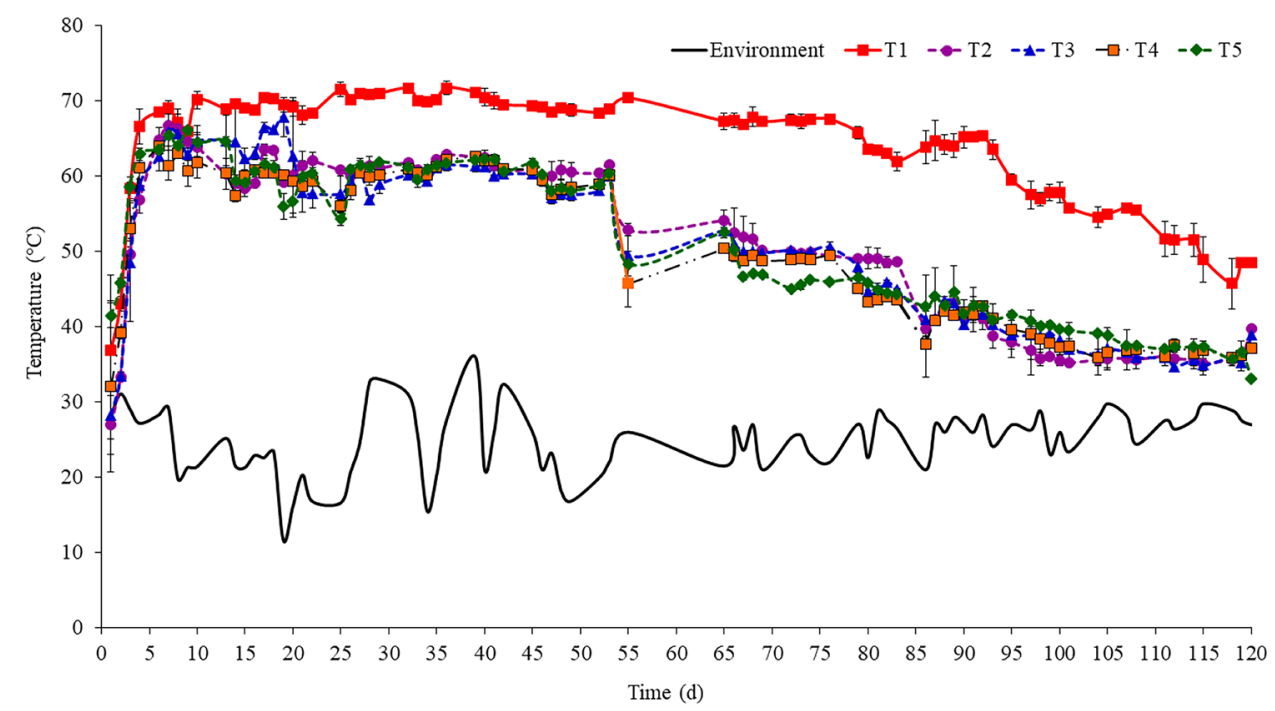


Fig. 2 Linear regression models to estimate variation in humidity (a), $\mathrm{pH}(\mathbf{b})$ and electrical conductivity (c) during 120 days of composting for treatments using distinct raw materials*. *T1 (control): sawdust and float sludge (50:50, v:v); T2: sawdust, float sludge and meal from dead pigs (50:20:30); T3: sawdust, float sludge and meal from dead pigs (50:10:40); T4: sawdust, stabilizing compost and meal from dead pigs (50:20:30); T5: sawdust, stabilizing compost and meal from dead pigs (50:30:20). The adopted limits (horizontal lines) are shown in Table 3

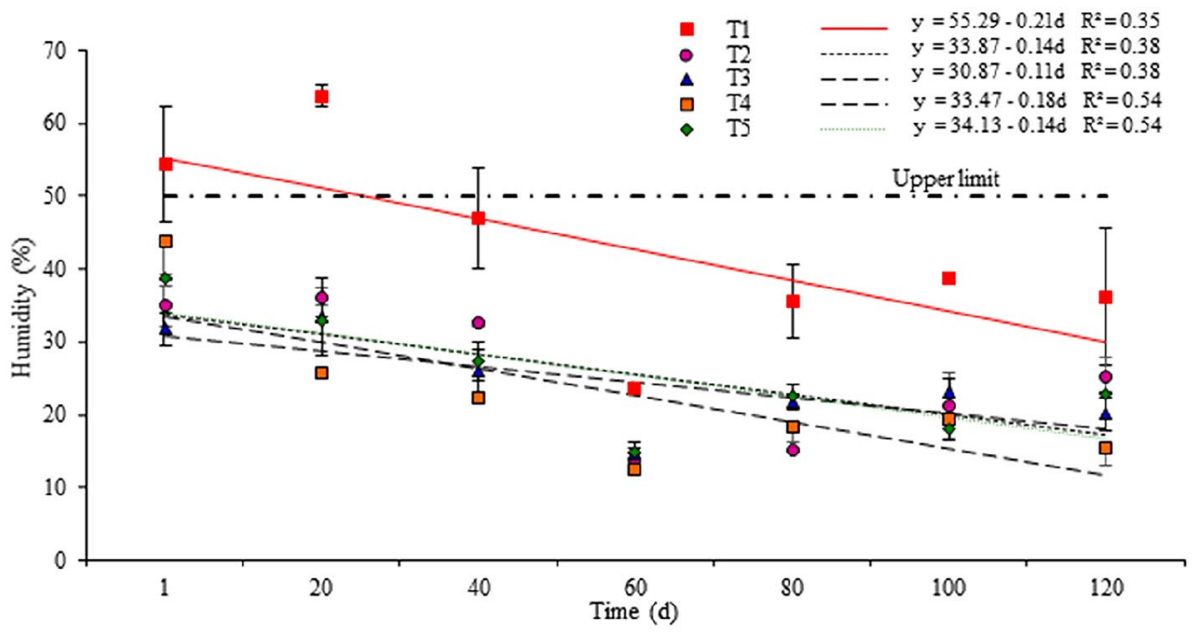

b
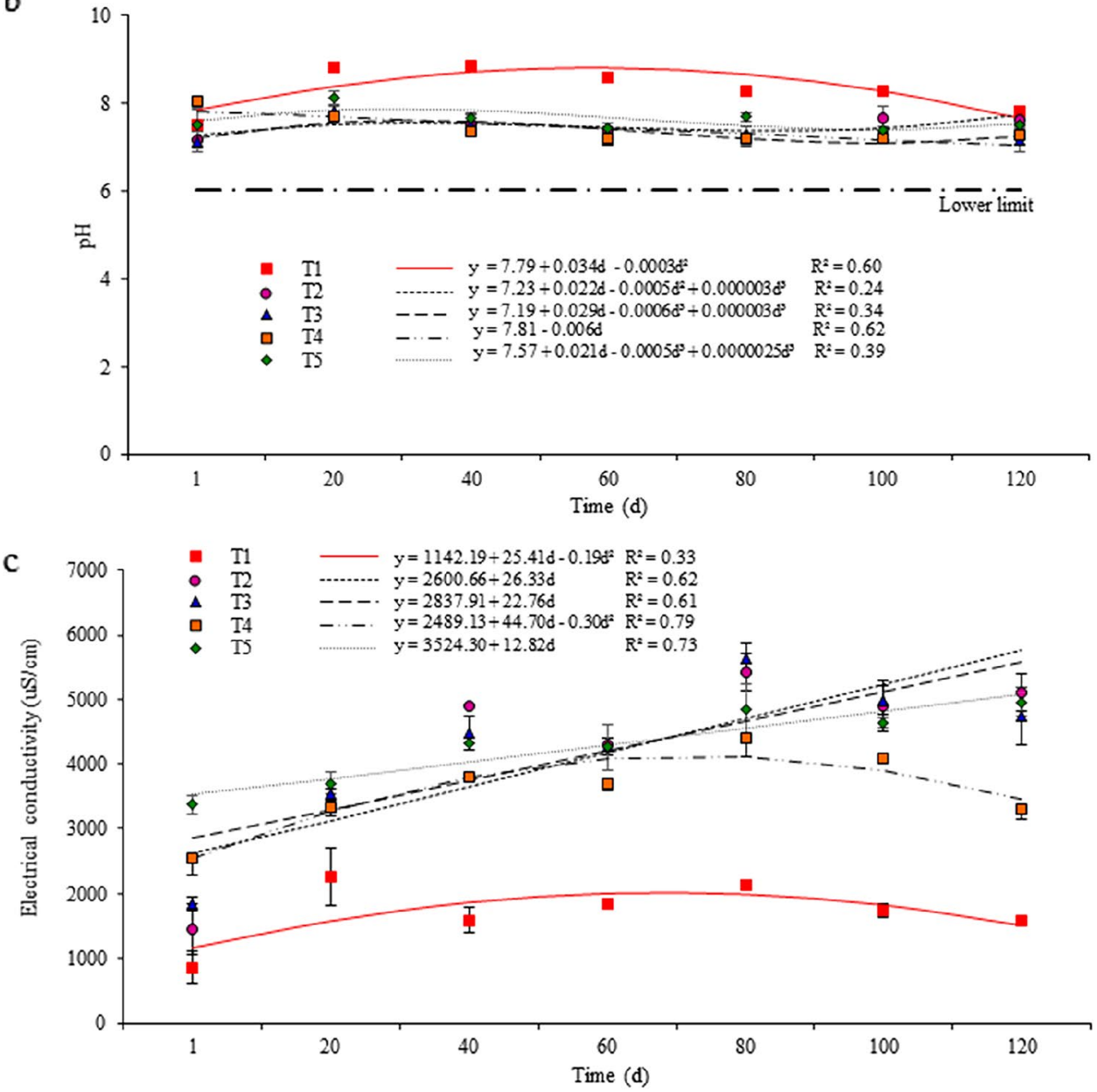

the inclusion of some content of slaughterhouse sludge or water, to avoid an excessive reduction in humidity, as occurred in $\mathrm{T} 4$, which reached the lowest humidity at the 120th day (Table 2, Fig. 2a). Additionally, the differences in temperatures among treatments are probably related to the fact that the humidity was inferior to $40 \%$ throughout the period for most treatments, except for the control. Under such conditions, the development of microorganisms, which require nearly $90 \%$ humidity, would be limited by the lack of water, which would contribute to reduce the metabolic activity inside the pile [34].

The mean $\mathrm{pH}$ observed in $\mathrm{T} 1$ tended to alkalinity (8.3) and was greater $(\mathrm{P}<0.05)$ than the mean $\mathrm{pH}$ observed in the other treatments (Table 2). A strong linear decrease in $\mathrm{pH}$ 
Fig. 3 Linear regression models to estimate variation in the content of total Kjeldahl N (a) C/N ratio (b), and in and phosphorus (c) during 120 days of composting for treatments using distinct raw materials*. *T1 (control): sawdust and float sludge (50:50, v:v); T2: sawdust, float sludge and meal from dead pigs (50:20:30); T3: sawdust, float sludge and meal from dead pigs (50:10:40); T4: sawdust, stabilizing compost and meal from dead pigs (50:20:30); T5: sawdust, stabilizing compost and meal from dead pigs (50:30:20). The adopted limits (horizontal lines) for are shown in Table 3

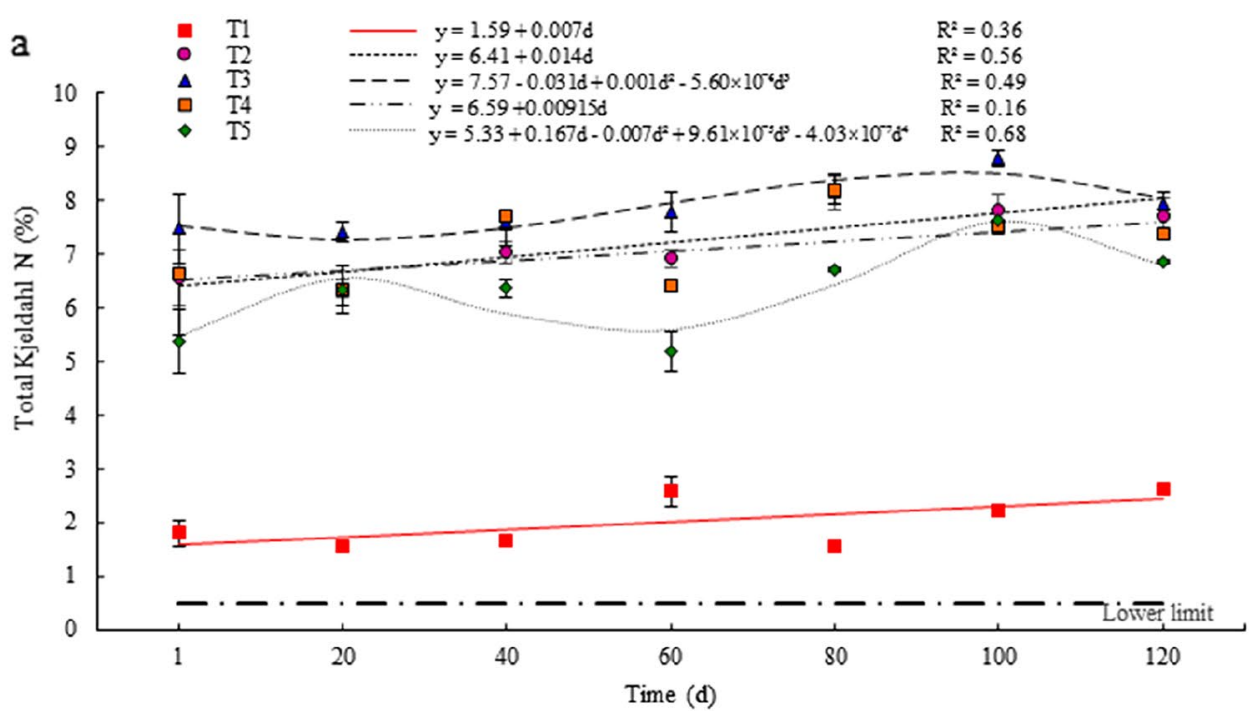

b
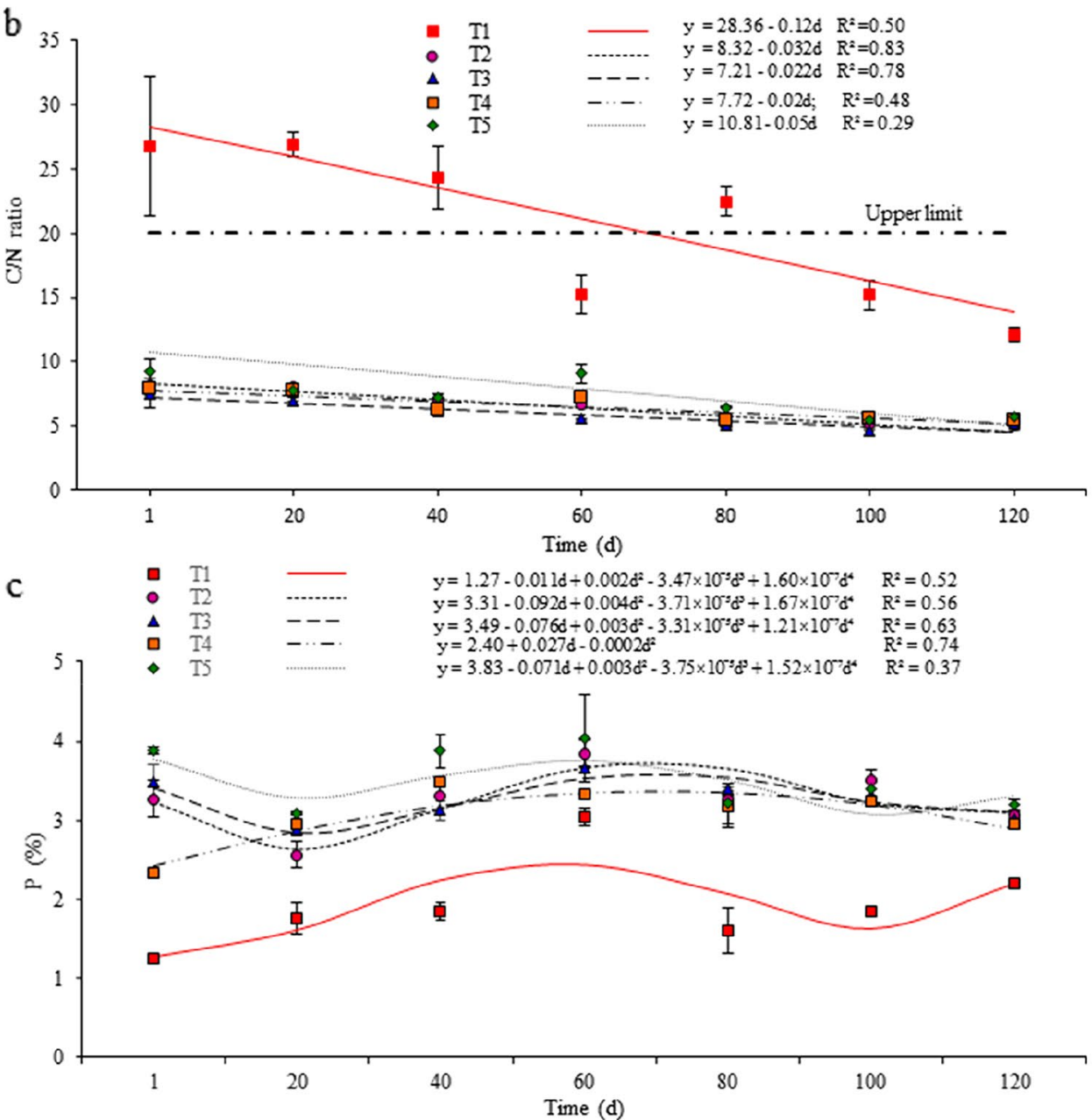

towards neutrality as the end of the period approached was observed in T4 (Fig. 2b), with a $\mathrm{R}^{2}$ of 0.62 and no polynomial effect. In T2, T3 and T5, the $\mathrm{pH}$ ranged between 7.3 and 7.6 (Table 2), following a cubic fluctuation over time (Fig. 2b). Although the model for $\mathrm{T} 1$ presented a $\mathrm{R}^{2}$ similar to that of $\mathrm{T} 4$, it presented a quadratic variation in $\mathrm{pH}$, which was greater than 8.0 at the second week of composting and peaked between the 20th and the 40th days (Fig. 2b), coinciding with the period with the highest temperatures. That may be due to an increased microbiological activity and to 
Table 2 Physicochemical parameters for distinct composting treatments using distinct raw materials (data collected at 1, 20, 40, 60, 80, 100 and 120 days; $\mathrm{n}=70$ )

\begin{tabular}{|c|c|c|c|c|c|c|}
\hline \multirow[t]{2}{*}{ Parameter } & \multicolumn{5}{|l|}{ Treatments* } & \multirow[t]{2}{*}{ Total } \\
\hline & $\mathrm{T} 1$ & $\mathrm{~T} 2$ & $\mathrm{~T} 3$ & $\mathrm{~T} 4$ & T5 & \\
\hline Humidity (\%) & $42.7 \pm 3.8^{\mathrm{a}}$ & $25.5 \pm 2.5^{\mathrm{bc}}$ & $24.4 \pm 1.8^{\mathrm{bc}}$ & $22.5 \pm 2.7^{\mathrm{c}}$ & $25.3 \pm 1.2^{\mathrm{b}}$ & $28.1 \pm 1.4$ \\
\hline $\mathrm{pH}$ & $8.3 \pm 0.1^{\mathrm{a}}$ & $7.5 \pm 0.1^{\mathrm{bc}}$ & $7.3 \pm 0.1^{\mathrm{c}}$ & $7.4 \pm 0.1^{\mathrm{bc}}$ & $7.6 \pm 0.1^{\mathrm{b}}$ & $7.6 \pm 0.1$ \\
\hline Electrical conductivity $(\mathrm{mS} / \mathrm{cm})$ & $1.8 \pm 0.1^{\mathrm{c}}$ & $4.7 \pm 0.2^{\mathrm{a}}$ & $4.6 \pm 0.2^{\mathrm{a}}$ & $3.8 \pm 0.1^{\mathrm{b}}$ & $4.4 \pm 0.5^{\mathrm{a}}$ & $3.8 \pm 0.1$ \\
\hline Total Kjedahl nitrogen (\%) & $2.0 \pm 0.1^{\mathrm{d}}$ & $7.2 \pm 0.2^{\mathrm{b}}$ & $7.9 \pm 0.2^{\mathrm{a}}$ & $7.2 \pm 0.2^{\mathrm{b}}$ & $6.4 \pm 0.2^{\mathrm{c}}$ & $6.1 \pm 0.2$ \\
\hline $\mathrm{C} / \mathrm{N}$ ratio & $20.4 \pm 1.7^{\mathrm{a}}$ & $6.5 \pm 0.4^{\mathrm{cd}}$ & $5.9 \pm 0.3^{\mathrm{d}}$ & $6.5 \pm 0.3^{b c}$ & $7.3 \pm 0.4^{\mathrm{b}}$ & $9.3 \pm 0.7$ \\
\hline Phosphorus (\%) & $2.0 \pm 0.2^{\mathrm{c}}$ & $3.3 \pm 0.1^{\mathrm{ab}}$ & $3.3 \pm 0.1^{\mathrm{b}}$ & $3.1 \pm 0.4^{\mathrm{b}}$ & $3.5 \pm 0.1^{\mathrm{a}}$ & $3.0 \pm 0.1$ \\
\hline
\end{tabular}

*T1 (control): sawdust and slaughterhouse sludge (50:50, v:v)

T2: sawdust, slaughterhouse sludge and meal from dead pigs (50:20:30)

T3: sawdust, slaughterhouse sludge and meal from dead pigs (50:10:40)

T4: sawdust, stabilizing compost and meal from dead pigs (50:20:30)

T5: sawdust, stabilizing compost and meal from dead pigs (50:30:20)

a,b,c Means \pm SEM with distinct superscripts differ in the lines across treatments $(\mathrm{P}<0.05)$

Table 3 Final compost quality for distinct composting treatments using distinct raw materials and technical specifications for quality and maturity considered in this study

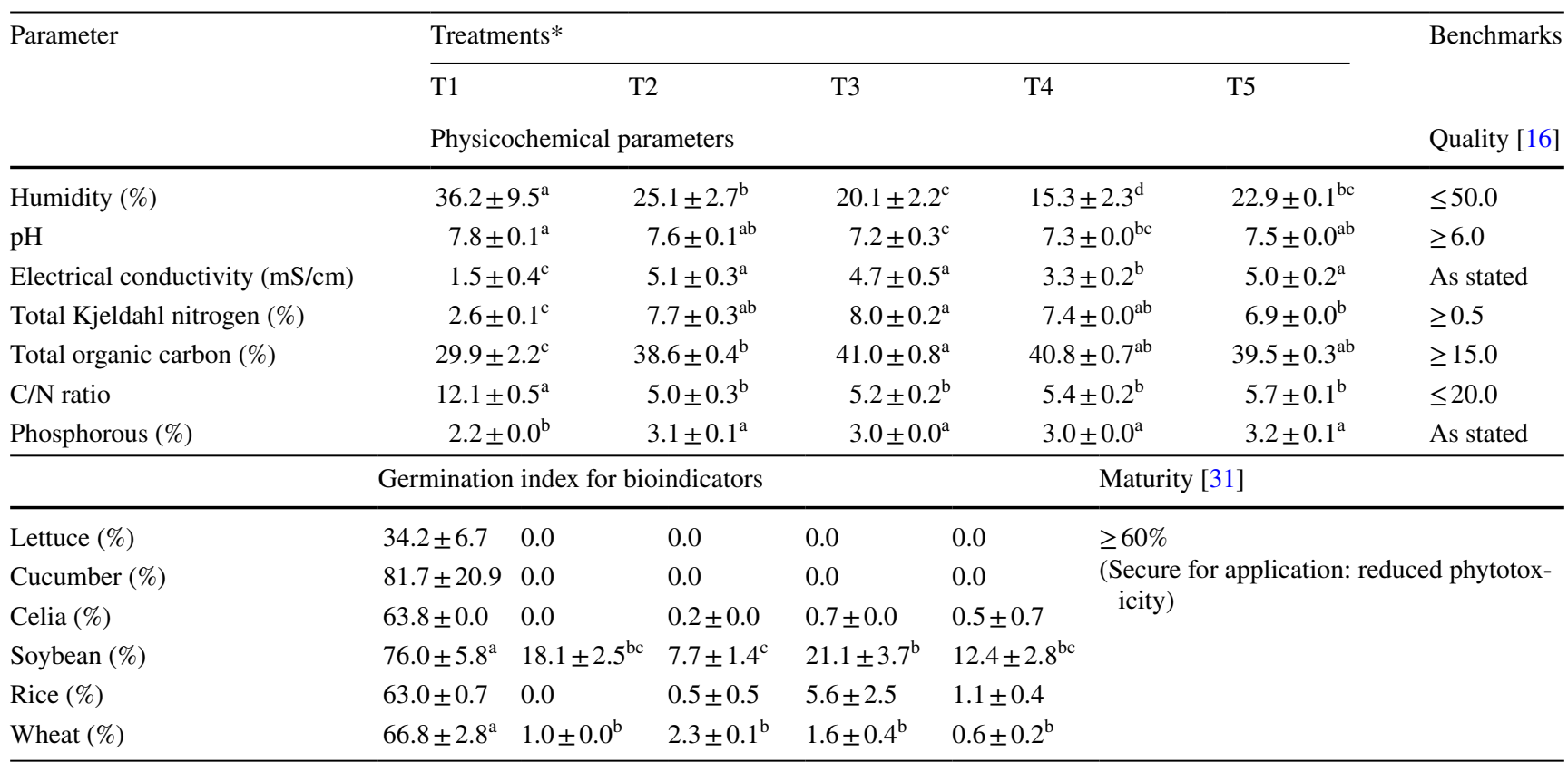

*T1 (control): sawdust and slaughterhouse sludge (50:50, v:v)

T2: sawdust, slaughterhouse sludge and meal from dead pigs (50:20:30)

T3: sawdust, slaughterhouse sludge and meal from dead pigs (50:10:40)

T4: sawdust, stabilizing compost and meal from dead pigs (50:20:30)

T5: sawdust, stabilizing compost and meal from dead pigs (50:30:20)

a,b,c Means \pm SEM with distinct superscripts differ in the lines across treatments $(\mathrm{P}<0.05)$

the nitrogen cycle during composting [35]. Changes in $\mathrm{pH}$ at the beginning of composting occur due to mineralization, when organic nitrogen is transformed in ammonium and ammonia through an alkaline reaction [36], increasing the $\mathrm{pH}$ inside the pile [35]. The subsequent decrease in $\mathrm{pH}$ may be related with the production of nitrate and the release of $\mathrm{H}^{+}$during nitrification [37]. Similar results were reported by Yang et al. [38], that reported final pH between 6.5 and 7.5 when composting swine carcasses, probably due the formation of low molecular weight fatty acids and $\mathrm{CO}_{2}$. 
Across treatments, the electrical conductivity was greater in $\mathrm{T} 2, \mathrm{~T} 3$ and $\mathrm{T} 5$ than in $\mathrm{T} 1$ and $\mathrm{T} 4(\mathrm{P}<0.05)$, but the control treatment presented the lowest electrical conductivity $(\mathrm{P}<0.05$, Table 2). In T2, T3 and T5, the electrical conductivity increased linearly as the composting period advanced, until values near to $5 \mathrm{mS} / \mathrm{cm}$ at the 120th day, as indicated by their linear regression models with $\mathrm{R}^{2}$ of at least 0.60 (Fig. 2c). The increased electrical conductivity observed in $\mathrm{T} 2$, T3 and T5 may be due to the protein and ashes content $(52 \%$ and $6 \%$, respectively) present in the meal from dead pigs, which represents $50 \%$ of the total content of such treatments [39]. That may also result from the reduction of the total volume of the materials and to the biotransformation of complex materials in simpler mineral components [17]. Composts with increased electrical conductivity, such as those resulting from T2, T3, T4 and T5 may lead to phytotoxicity, impairing vegetable growth and germination, indicating that they should be mixed with materials or soils with reduced electrical conductivity before their use in agriculture [40]. However, even though T4 also presented greater electrical conductivity than the control $(\mathrm{P}<0.05)$, its temporal variation was nonlinear due a quadratic effect: the electrical conductivity increased until nearly the 60th day; but stabilized thereafter, showing even a slight decrease after the 80th day of composting period (Fig. 2c). That may have occurred due to either volatilization of ammonia or precipitation of mineral salts [41].

At the first day of the experiment, the total organic carbon content was similar for all treatments $(\mathrm{P}>0.05)$, but generally declined as composting advanced (Table S1). In the control, the decline was already evident at the 40th day, although the content of total organic carbon was inferior to those of the other treatments at all three subsequent periods $(\mathrm{P}<0.05)$, signaling an increase in the content of mineral matter in the piles. In T2 and T3, which included greater content of meal from dead pigs (more than 20\%) or no stabilizing compost, the decline was slower, after the 80th day (Table S1). That may be due to the excess of nitrogen and to the low humidity in the pile, which would limit microorganism development. In fact, depending on the particle size and on the environmental temperature, animal protein-rich wastes may require 4-12 months to be completely composted [42].

The mean concentration of TKN in the control treatment (2.0\%) was lower than those of all other tested treatments $(\mathrm{P}<0.05)$, which were at least three-fold greater (Table 2). Among the treatments including meal from dead pigs, T3 presented the greatest TKN content $(\mathrm{P}<0.05)$. In all treatments, including the control, the TKN content was above the established lower limit (Table 3), during the entire composting period and generally increased over time (Fig. 3a). Such an increase was more characteristic from the 60th day (Fig. 3a), when the temperatures generally dropped
(Fig. 1), characterizing the change from the thermophilic to the mesophilic phase, when the revolving interval of the piles was reduced to each 25 days. At the end of the composting period, the content of TKN was $>6 \%$ in all treatments, except T1 (Fig. 3a). As the composting period progressed, a slight linear increase in the TKN content was observed in T4. As indicated by the linear regression model applied to T4, only $16 \%$ of the total variation in the content of TKN would be explained by the extension of composting (Fig. 3a). Linear increase in TKN content over time was also observed in $\mathrm{T} 1$ and $\mathrm{T} 2$, both with stronger linear associations with composting time than $\mathrm{T} 4$, although $\mathrm{T} 1$ presented lower mean TKN content throughout the entire composting period. Nevertheless, in T3 and T5, the polynomial effects fitted by the linear regression models revealed that the increase in the TKN content was nonlinear (Fig. 3a), since it fluctuated during the composting period and decreased after the 100th day. Losses in TKN are common during composting, especially for mixtures with low $\mathrm{C} / \mathrm{N}$ ratio at the beginning of the process. Such losses may be due to the volatilization of ammonia during the thermophilic phase [15].

The $\mathrm{C} / \mathrm{N}$ ratio was greater in $\mathrm{T} 1(\mathrm{P}<0.05)$ than in the other treatments (Table 2), but it decreased linearly for all treatments as composting was prolonged (Fig. 3b). The control treatment presented a nearly ideal high $\mathrm{C} / \mathrm{N}$ ratio at the beginning of the period and showed a steep decline, as expected, becoming lower than the established upper limit after 60 days and dropping to nearly 14/1 at the 120th day (Fig. 3b). On the other hand, despite of the differences among the treatments including meal from dead pigs shown in Table 2, the $\mathrm{C} / \mathrm{N}$ ratio in all such treatments was much lower than the established upper limit since the beginning of the composting period (Fig. $3 \mathrm{~b}$ ). The greatest $\mathrm{C} / \mathrm{N}$ ratio was observed in $\mathrm{T} 5(\mathrm{P}<0.05)$, whereas the lowest was observed in T3 (Table 2), which included $40 \%$ of meal from dead pigs and the greatest nitrogen content among all tested treatments. The best initial $\mathrm{C} / \mathrm{N}$ ratio for composting is usually considered 25-30/1 [19]. The linear decrease in the $\mathrm{C} / \mathrm{N}$ ratio observed in all treatments over time would likely lead to an increased emission of both $\mathrm{NH}_{3}$ and $\mathrm{N}_{2} \mathrm{O}$ [43].

Compared to the control, all other treatments presented greater total phosphorous content $(\mathrm{P}<0.05)$, with the greatest content observed in T5 (Table 2). Although all five treatments showed oscillations in the phosphorus content throughout the composting period, such content was somewhat stabilized within 60-80 days, presenting a slight reduction after that period (Fig. 3c). Generally, that variation was nonlinear for all treatments (Fig. 3c), even in T1, which presented the lowest overall phosphorous content (Table 2). That likely reflected an increase in inorganic fractions, concomitant with an increasingly degradation of the organic matter [44]. 
Fig. 4 Germination index (GI) for lettuce (L. sativa) (a), cucumber (C. sativus) (b), celia (C. argentea) $(\mathbf{c})$, soybean $(G$. max) (d), rice (O. sativa) (e) and wheat (T. aestivum) (f) at three composting periods for treatments using distinct raw materials*. *T1 (control): sawdust and float sludge (50:50, v:v); T2: sawdust, float sludge and meal from dead pigs (50:20:30); T3: sawdust, float sludge and meal from dead pigs (50:10:40); T4: sawdust, stabilizing compost and meal from dead pigs (50:20:30); T5: sawdust, stabilizing compost and meal from dead pigs (50:30:20). $\mathrm{A}, \mathrm{B}, \mathrm{C}$ Means (SEM) with distinct superscripts differ across periods by at least $\mathrm{P}<0.05$.

${ }_{\mathrm{a}, \mathrm{b}, \mathrm{c}}$ Means (SEM) with distinct superscripts differ across treatments by at least $\mathrm{P}<0.05$. The adopted limits (horizontal lines) are shown in Table 3
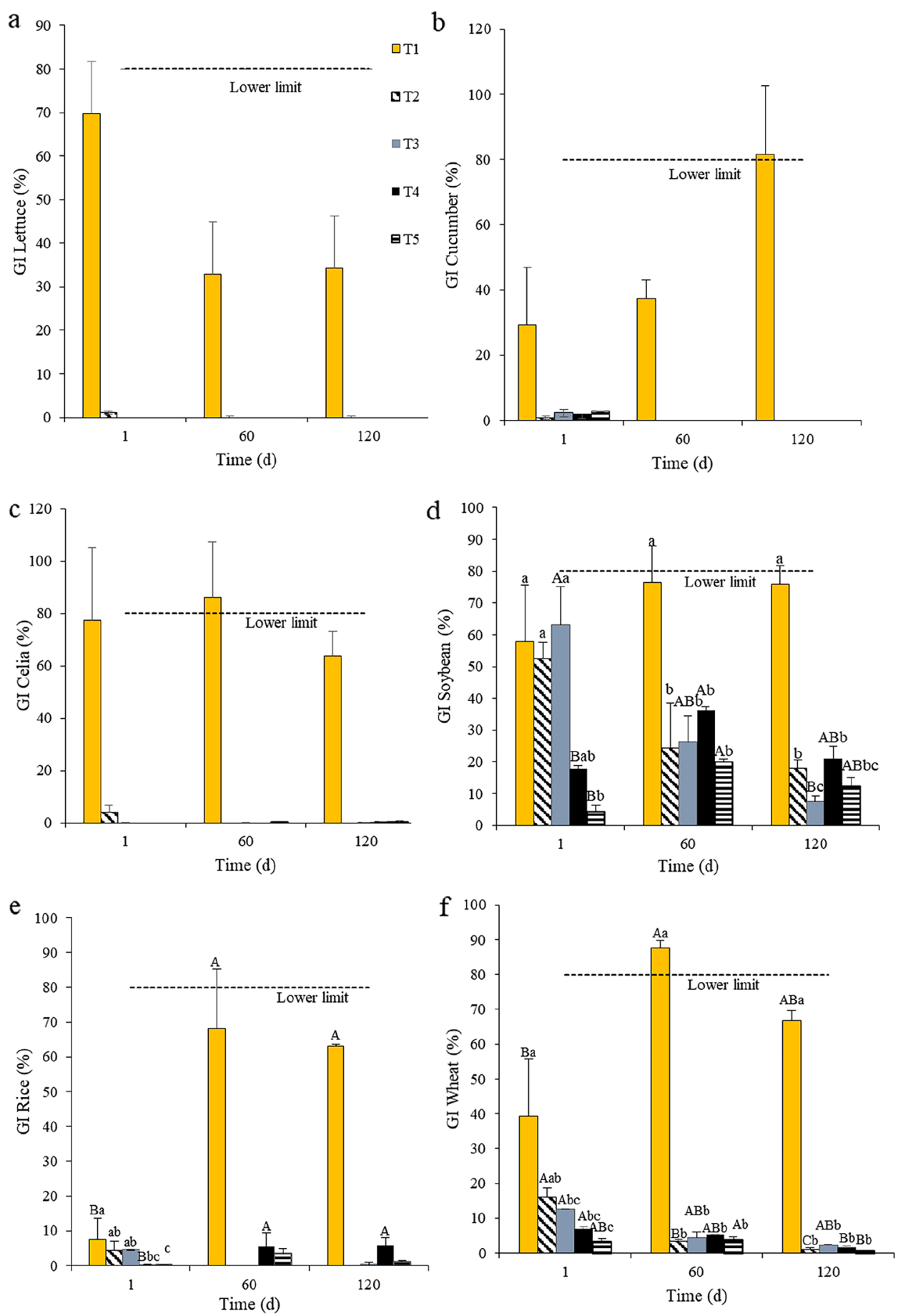

\section{Phytotoxicity Assays}

Lettuce, cucumber and celia were the bioindicators most sensitive to phytotoxicity. Compared to the control, those seeds presented impaired germination in all other treatments already at the first day of composting (Fig. 4a-c), which also occurred during the remaining of the composting period $(\mathrm{P}<0.05)$. For both lettuce (Fig. $4 a)$ and cucumber seeds (Fig. 4b), there was no germination in any treatment including meal from dead pigs within the 60th and the 120th days of composting.

At the first day of composting, the GI of soybean seeds was similarly high in T1, T2 and T3 $(\mathrm{P}>0.05)$, but lower in $\mathrm{T} 4$ and $\mathrm{T} 5(\mathrm{P}<0.05$, Fig. $4 \mathrm{~d})$. As composting was prolonged, the GI of soybean seeds became greater in the control compared to the other treatments $(\mathrm{P}<0.05)$. At the end of the period, T3 was the most phytotoxic treatment for soybean seeds (Fig. 4d). 
The GI of rice seeds in T4 was greater at both the 60st and the 120th days of composting than at the first day (Fig. 4e), although the GI of rice seeds in all treatments including meal from dead pigs remained lower than the GI of the control during the entire period $(\mathrm{P}<0.05)$.

For wheat seeds, the IG decreased in all treatments including meal from dead pigs at 120th day of composting $(\mathrm{P}<0.05)$ compared to the initial period (Fig. 4f). Those distinct responses among seeds may reflect differences in their metabolic reserves and resistance mechanisms.

\section{Quality and Maturity of the Final Compost}

As temperatures required for effective sanitization must be kept for at least $1 \mathrm{~h}$ for composting of animal by-products [15], the composts from all treatments can be considered efficient for pathogen inactivation [45], as the temperature during composting remained above $55^{\circ} \mathrm{C}$ for more than three days.

Considering their physicochemical characteristics, all treatments reached the requirements for agronomic quality (Table 3 ). Although all composts presented a slightly alkaline final $\mathrm{pH}$, the final $\mathrm{pH}$ of the compost from $\mathrm{T} 1$ was higher than those from T3 and T4 $(\mathrm{P}<0.05)$. Additionally, the electrical conductivity of the composts from all treatments including meal from dead pigs was greater compared to $\mathrm{T} 1(\mathrm{P}<0.05)$. On the other hand, the final compost obtained from all treatments including meal from dead pigs presented less humidity, lower $\mathrm{C} / \mathrm{N}$ ratio and greater content of organic carbon, nitrogen and phosphorus compared to the control treatment $(\mathrm{P}<0.05)$. Those findings suggest that composts from such treatments would have superior agronomic value than the compost from T1. Nevertheless, the decomposition of organic matter that occurs inside the pile during intermediate stages of composting may lead to the release of fatty acids that would induce phytotoxicity [46]. The high content of fat, characteristic of materials of animal origin, can also be related to increased phytotoxicity, which may be minimized by prolonging the composting period (e.g., up to 180 days). As composting is prolonged, the total content of organic carbon is reduced, reducing the $\mathrm{C} / \mathrm{N}$ ratio and increasing the availability of nitrogen, which may be released as ammonia. Furthermore, mixtures rich in nitrogen may release high content of soluble salts in the pile, which would lead to an increase in electrical conductivity [33]. Thus, the low GI observed at the end of composting for all tested treatments was more likely due to their increased electrical conductivity. Since their electrical conductivity was above $4.0(\mathrm{mS} / \mathrm{cm})$, the composts from $\mathrm{T} 2, \mathrm{~T} 3$ and $\mathrm{T} 5$ would be considered immature [17]. As the $\mathrm{C} / \mathrm{N}$ ratio is also an indicator of compost stabilization, the control (T1) was the only treatment presenting $\mathrm{C} / \mathrm{N}$ ratio within the range of $10 / 1$ to $20 / 1$ recommended for stable composts [16, 47].
All tested bioindicators germinated when placed in contact with the compost obtained from the control treatment (Table 3). However, celia and rice seeds presented only some slim germination in contact with composts from T3, T4 and T5 (with very low GI), whereas lettuce and cucumber seeds did not germinate in contact with any compost from treatments including meal from dead pigs. Furthermore, no germination at all was observed for such seeds when in contact with the compost from T2. Thus, although the germination of celia, rice, lettuce and cucumber seeds was clearly impaired when they were in contact with composts from the treatments including meal from dead pigs, no statistical comparisons could be made because their GI presented either values equal to 0 (zero) or great dispersion due to a large variation present within the treatments.

Soybean and wheat seeds were the only bioindicators that presented relevant germination in contact with composts from treatments including meal from dead pigs, even though their GI were lower compared to the control compost $(\mathrm{P}<0.05)$. Therefore, the GI shown in Table 3 indicate that the composts obtained from all treatments including meal from dead pigs presented toxicity for all tested bioindicators. Since a compost secure for application should yield a GI equal or $>60 \%$ for any bioindicator [31], the compost from $\mathrm{T} 1$ can be considered phytotoxic only for lettuce seeds. However, the compost from the control treatment, which did not include meal from dead pigs, was the only one that allowed sustained germination of the other tested seeds during the whole period and generated a mature compost, as indicated by the GI $>80 \%$ observed for cucumber and soybean seeds [30]. On the other hand, as the slaughterhouse sludge content in the pile was reduced to include other materials in $\mathrm{T} 2$, T3, T4 and T5, their final compost was phytotoxic for all tested bioindicators and should be considered immature [48], despite of the fact that some of their physicochemical parameters were at acceptable levels. Due to those acceptable physicochemical characteristics, the inclusion of meal from dead pigs may be tested in future studies at levels lower than those tested in the present study (e.g., below 20\%,), to attempt to reduce their toxicity, so the resulting compost may become an alternative organic fertilizer that may contribute to reduce the use of chemical fertilizers in agriculture.

\section{Conclusions}

The inclusion of meal from dead pigs produced by rendering plants in composting treatments using distinct raw materials from agro-industrial wastes resulted in nutrientrich composts, which may have potential agricultural use as organic fertilizers. However, such composts were phytotoxic for all seeds tested as bioindicators (cucumber, 
lettuce, rice, celia, soybean and wheat) and were not considered stable, since they presented high electrical conductivity outside the recommended level.

Supplementary Information The online version contains supplementary material available at https://doi.org/10.1007/s12649-021-01422-0.

Acknowledgements The authors thank CAPES and CNPq for their financial support.

\section{References}

1. USDA. United States Department of Agriculture. Livestock and Poultry: World markets and trade. Foreign Agricultural Service, Oct 11 (2018)

2. Alvarenga, P., Mourinha, C., Farto, M., Santos, T., Palma, P., Sengo, J., Morais, M.C., Cunha-Queda, C.: Sewage sludge, compost and other representative organic wastes as agricultural soil amendments: benefits versus limiting factors. Waste Manag. (2015). https://doi.org/10.1016/j.wasman.2015.01.027

3. Zheng, J.L., Zhu, M., Wu, H.: Alkaline hydrothermal liquefaction of swine carcasses to bio-oil. Waste Manag. (2015). https://doi. org/10.1016/j.wasman.2015.05.010

4. Zhao, D., Liu, R., Zhang, X., Li, F., Wang, J., Zhang, J., Liu, X., Wang, L., Zhang, J., Wu, X., Guan, Y., Chen, W., Wang, X., He, $\mathrm{X}$., $\mathrm{Bu}, \mathrm{Z}$.: Replication and virulence in pigs of the first African swine fever virus isolated in China. Emerg. Microbes Infect. (2019). https://doi.org/10.1080/22221751.2019.1590128

5. Gortázar, C., de la Fuente, J.: COVID-19 is likely to impact animal health. Prev. Vet. Med. (2020). https://doi.org/10.1016/j.preve tmed.2020.105030

6. Gwyther, C.L., Williams, A.P., Golyshin, P.N., Jones, G.E., Jones, D.L.: The environmental and biosecurity characteristics of livestock carcass disposal methods: a review. Waste Manag. (2011). https://doi.org/10.1016/j.wasman.2010.12.005

7. Imbeah, M.: Composting piggery waste: a review. Bioresour. Technol. (1998). https://doi.org/10.1016/S0960-8524(97)00165-X

8. Tyagi, V.K., Lo, S.L.: Sludge: a waste or renewable source for energy and resources recovery? Renew. Sust. Energy Rev. 25, 708-728 (2013)

9. Brazilian Ministry of Agriculture, Livestock and Supply. Instrução Normativa $n^{\circ} 48$ de Outubro (2019)

10. Kalbasi-Ashtari, A., Schutz, M.M., Auvermann, B.W.: Carcass rendering systems for farm mortalities: a review. J. Environ. Eng. Sci. (2008). https://doi.org/10.1139/S07-051

11. Conesa, J.A., Fullana, A., Font, R.: Dioxin production during the thermal treatment of meat and bone meal residues. Chemosphere (2005). https://doi.org/10.1016/j.chemosphere.2004.09.089

12. Spångberg, J., Hansson, P.A., Tidåker, P., Jönsson, H.: Environmental impact of meat meal fertilizer vs. chemical fertilizer. Resour. Conserv. Recycl. (2011). https://doi.org/10.1016/j.resco nrec.2011.06.002

13. Hidalgo, D., Martín-Marroquín, J.M., Corona, F.: The effect of feed composition on anaerobic co-digestion of animal-processing by-products. J. Environ. Manag. (2018). https://doi.org/10.1016/j. jenvman.2017.06.033

14. Cayuela, M.L., Mondini, C., Insam, H., Sinicco, T., Whittle, I.F.: Plant and animal wastes composting: effects of the $\mathrm{N}$ source on process performance. Bioresour. Technol. 100, 3097-3106 (2009)

15. Barrena, R., Artola, A., Vázquez, F., Sánchez, A.: The use of composting for the treatment of animal by-products: experiments at lab scale. J Hazard. Mater. (2009). https://doi.org/10.1016/j. jhazmat.2008.03.109

16. Brazilian Ministry of Agriculture, Livestock and Supply: Instrução Normativa $\mathrm{n}^{\circ} 25,23$ de julho de 2009

17. Onwosi, C.O., Igbokwe, V.C., Odimba, J.N., Eke, I.E., Nwankwoala, M.O., Iroh, I.N., Ezeogu, L.I.: Composting technology in waste stabilization: on the methods, challenges and future prospects. J. Environ. Manag. (2017). https://doi.org/10.1016/j.jenvm an.2016.12.051

18. Huang, G.F., Wong, J.W.C., Wu, Q.T., Nagar, B.B.: Effect of C/N on composting of pig manure with sawdust. Waste Manag. (2004). https://doi.org/10.1016/j.wasman.2004.03.011

19. Kumar, M., Ou Yan, L., Lin, J.G.: Co-composting of green waste and food waste at low C/N ratio. Waste Manag. (2010). https:// doi.org/10.1016/j.wasman.2009.11.023

20. Golueke, C.G., Card, B.J., Mcgauhey, P.H.: A critical evaluation of inoculums in composting. Appl. Microbiol. 2, 45-53 (1954)

21. Alfano, G., Belli, C., Lustrato, G., Ranalli, G.: Pile composting of two-phase centrifuged olive husk residues: technical solutions and quality of cured compost. Bioresour. Technol. (2008). https:// doi.org/10.1016/j.biortech.2007.09.080

22. Karnchanawong, S., Nissaikla, S.: Effects of microbial inoculation on composting of household organic waste using passive aeration bin. Int. J. Recycl. Org. Waste Agric. (2014). https://doi.org/10. 1007/s40093-014-0072-0

23. Corrêa, É.K., Ulguim, R.R., Corrêa, L.B., Castilhos, D.D., Bianchi, I., Gil-Turnes, C., Lucia, T., Jr.: Addition of Bacillus sp. inoculums in bedding for swine on a pilot scale: effect on microbial population and bedding temperature. Bioresour. Technol. (2012). https://doi.org/10.1016/j.biortech.2012.06.033

24. Khan, N., Clark, I., Miguel, A., Monedero, S., Shea, S., Meier, S., Bolan, N.: Maturity indices in co-composting of chicken manure and sawdust with biochar. Bioresour. Technol. (2014). https://doi. org/10.1016/j.biortech.2014.02.123

25. Qian, X., Shen, G., Wang, Z., Guo, C., Liu, Y., Lei, Z., Zhang, $\mathrm{Z}$.: Co-composting of livestock manure with rice straw: characterization and establishment of maturity evaluation system. Waste Manag. (2014). https://doi.org/10.1016/j.wasman.2013.10.007

26. Blazy, V., de Guardia, A., Benoist, J.C., Daumoin, M., Guiziou, F., Lemasle, M., et al.: Correlation of chemical composition and odor concentration for emissions from pig slaughterhouse sludge composting and storage. Chem. Eng. J. 276, 398-409 (2015)

27. Oliveira, J.J., Dalmazo, G.O., Morselli, T.B.G.A., Oliveira, V.F.S., Corrêa, L.B., Nora, L., Corrêa, E.K.: Composted slaughterhouse sludge as a substitute for chemical fertilizers in the cultures of lettuce (Lactuca sativa L.) and radish (Raphanus sativus L.). J. Food Sci. Technol. (2018). https://doi.org/10.1590/1678-457x.00717

28. Bohrer, R.E.G., Carissimi, E., Wolf, D.B., Prestes, O.D., Zanella, R., Rizzetti, T.M., Lopez, D.A.R., Da Silva, D.M.: Removal of high concentrations of veterinary antibiotics through co-composting of swine waste. Waste Biomass Valoriz. (2020). https://doi. org/10.1007/s12649-020-00952-3

29. Mendes, P.M., Becker, R., Corrêa, L.B., Bianchi, I., Dai Prá, M.A., Lucia, T., Jr., Corrêa, E.K.: Phytotoxicity as an indicator of stability of broiler production residues. J. Environ. Manag. (2016). https://doi.org/10.1016/j.jenvman.2015.11.031

30. Tiquia, S.M., Tam, N.F.Y., Hodgkiss, I.J.: Effects of composting on phytotoxicity of spent pig-manure sawdust litter. Environ. Pollut. (1996). https://doi.org/10.1016/S0269-7491(96)00052-8

31. Gómez-Brandón, M., Lazcano, C., Domínguez, J.: The evaluation of stability and maturity during the composting of cattle manure. Chemosphere 70, 436-444 (2008). https://doi.org/10.1016/j. chemosphere.2007.06.065

32. California Compost Quality Council. Compost Maturity Index. Technical Report. California (2001) 
33. Komilis, D., Evangelou, A., Voudrias, E.: Monitoring and optimizing the co-composting of dewatered sludge: a mixture experimental design approach. J. Environ. Manag. (2011). https://doi. org/10.1016/j.jenvman.2011.04.012

34. Kebibeche, H., Khelil, O., Kacem, M., Harche, K.M.: Addition of wood sawdust during the co-composting of sewage sludge and wheat straw influences seeds germination. Ecotoxicol. Environ. Saf. (2019). https://doi.org/10.1016/j.ecoenv.2018.10.075

35. Nolan, T., Troy, S.M., Healy, M.G., Kwapinski, W., Leahy, J.J., Lawlor, P.G.: Characterization of compost produced from separated pig manure and a variety of bulking agents at low initial $\mathrm{C} / \mathrm{N}$ ratios. Bioresour. Technol. (2011). https://doi.org/10.1016/j.biort ech.2011.04.066

36. Hao, X., Benke, M.B.: Nitrogen transformation and losses during composting and mitigation strategies. Dyn. Soil Dyn. Plant 2(Special issue 1), 10-18 (2008)

37. Eklind, Y., Kirchmann, H.: Composting and storage of organic household waste with different litter amendments. II: nitrogen turnover and losses. Bioresour. Technol. (2000). https://doi.org/ 10.1016/S0960-8524(00)00005-5

38. Yang, X.C., Han, Z.Z., Ruan, X.Y., Chai, J., Jiang, S.W., Zheng, R.: Composting swine carcasses with nitrogen transformation microbial strains: succession of microbial community and nitrogen functional genes. Sci. Total Environ. (2019). https://doi.org/ 10.1016/j.scitotenv.2019.06.283

39. Auvermann, B., Kalbasi, A., Ahmed, A.: Carcass disposal: a comprehensive review. Chapter 4-Rendering. Manhattan, NY: USDA. Animal and plant health inspection serv. coop. agreement project and carcass disposal working group (2004)

40. Awasthi, M.K., Pandey, A.K., Khan, J., Bundela, P.S., Wong, J.W.C., Selvam, A.: Evaluation of thermophilic fungal consortium for organic municipal solid waste composting. Bioresour. Technol. (2014). https://doi.org/10.1016/j.biortech.2014.01.048

41. Wong, J.W.C., Mak, K.F., Chna, N.W., Lam, A., Fang, M., Zhou, L.X., Wu, Q.T., Liao, X.D.: Co-composting of soybean residues and leaves in Hong Kong. Bioresour. Technol. 76, 99-106 (2001)
42. Gooding, C., Meeker, D.: Review: Comparison of 3 alternatives for large-scale processing of animal carcasses and meat by-products. Prof. Anim. Sci. 32, 259-270 (2016). https://doi.org/10. 15232/pas.2015-01487

43. Amlinger, F., Peyr, S., Cuhls, C.: Greenhouse gas emissions from composting and mechanical biological treatment. Waste Manag. Res. 26, 47-60 (2008). https://doi.org/10.1177/0734242X07 088432

44. Wei, Y., Zhao, Y., Xi, B., Wei, Z., Li, X., Cao, Z.: Changes in phosphorus fractions during organic wastes composting from different sources. Bioresour. Technol. (2015). https://doi.org/10. 1016/j.biortech.2015.04.031

45. Ahn, H.K., Sauer, T.J., Richard, T.L., Glanville, T.D.: Determination of thermal properties of composting bulking materials. Bioresour. Technol. (2009). https://doi.org/10.1016/j.biortech.2008.11. 056

46. Barral, M.T., Paradelo, R.: A review on the use of phytotoxicity as a compost quality indicator. Dyn. Soil Dyn. Plant 5, 36-44 (2011)

47. Komilis, D.P., Tziouvaras, I.S.: A statistical analysis to assess the maturity and stability of six composts. Waste Manag. 29, 1504 1513 (2009). https://doi.org/10.1016/j.wasman.2008.10.016

48. Zhou, Y., Selvam, A., Wong, J.W.: Evaluation of humic substances during co-composting of food waste, sawdust and Chinese medicinal herbal residues. Bioresour. Technol. (2014). https://doi.org/10. 1016/j.biortech.2014.05.070

Publisher's Note Springer Nature remains neutral with regard to jurisdictional claims in published maps and institutional affiliations. 